\title{
PERAN KUALITAS PELAYANAN DALAM MEMEDIASI PENGARUH TOTAL QUALITY MANAGEMENT TERHADAP KEPUASAN KONSUMEN SEPEDA BALI TOUR
}

\author{
I Gede Bayu Mertha Segara ${ }^{1}$ \\ Gede Merta Sudiartha ${ }^{2}$
${ }^{1,2}$ Fakultas Ekonomi dan Bisnis Universitas Udayana (Unud), Bali, Indonesia
E-mail: bayunesa@gmail.com

\begin{abstract}
ABSTRAK
Persaingan bisnis yang semakin ketat serta semakin berubahnya kebutuhan konsumen membuat perusahaan harus selalu mampu memberikan kepuasan kepada konsumen agar mampu bersaing dengan pesaingnya. Penerapan total quality management dapat meningkatkan kinerja perusahaan dalam memberikan kepuasan kepada konsumen. Selain itu dengan memberikan kualitas pelayanan yang baik kepada konsumen akan memberikan kepuasan yang lebih besar kepada konsumen. Tujuan dari penelitian ini adalah untuk mengetahui peran dari kualitas pelayanan dalam memediasi pengaruh total quality management terhadap kepuasan konsumen.Penelitian ini dilakukan di Sepeda Bali Tour, dengan jumlah responden yaitu 200 orang konsumen Sepeda Bali Tour. Metode yang digunakan adalah nonprobability sampling khususnya purposive sampling dengan teknik analisis data menggunakan path analysis dan uji sobel. Berdasarkan hasil analisis yang dilakukan didapatkan hasil bahwa variabel kualitas pelayanan mampu memediasi pengaruh penerapan total quality management terhadap kepuasan konsumen. Uji path analysis menunjukan bahwa pengaruh langsung variabel total quality management terhadap kepuasan konsumen memiliki nilai koefisien beta sebesar 0,386 sedangkan pengaruh tidak langsung yang dimediasi oleh kualitas pelayanan menunjukan nilai koefisien beta sebesar 0,489 . Sedangkan hasil uji sobel didapatkan nilai $\mathrm{Z}$ hitung sebesar 12,0123 yaitu lebih besar dari 1,96 ( $\mathrm{Z}$ hitung 12,0127 > 1,96) yang berarti kualitas pelayanan mampu memediasi total quality management terhadap kepuasan konsumen
\end{abstract}

Kata Kunci :total quality management (tqm), kualitas pelayanan, kepuasan konsumen

\begin{abstract}
Increasingly business competition and the changing needs of consumers make companies must always give satisfaction to consumers in order to compete with competitors. The application of total quality management can improve company performance in providing satisfaction to consumers. In addition, by providing good quality service to consumers, it will give more greater satisfaction on consumers. The purpose of this study was to determine the role of service quality in mediating the effect of total quality management on customer satisfaction.This research was conducted at Sepeda Bali Tour with 200 respondents, consumers of Sepeda Bali Tour. The method used is nonprobability sampling, especially purposive sampling with data analysis techniques using path analysis and sobel test.Based on the results of the path analysis test shows that the direct effect of the total quality management variable on customer satisfaction has a beta coefficient of 0.386 while the indirect effect mediated by service quality shows a beta coefficient of 0.489. While the results of the sobel test obtained a calculated $Z$ value of 12.0123 which is greater than 1.96 ( $Z$ count 12.0127> 1.96) which means that service quality is able to mediate total quality management on customer satisfaction
\end{abstract}

Keyword :total quality management (tqm), service quality, consumer satisfaction 
I Gede Bayu Mertha Segara,Peran Kualitas Pelayanan...

\section{PENDAHULUAN}

Persaingan bisnis dewasa ini berlangsung semakin ketat akibat perubahan teknologi, perkembangan dunia bisnis serta perubahan kebutuhan konsumen. Agar bersaing dalam bisnis yang kompetitif, pelaku bisnis harus mengetahui berbagai kebutuhan dan keinginan konsumen (Tjiptono, 2001 : 23). Jika perusahaan mampu memenuhi segala kebutuhan dan keinginan para konsumennya maka akan memberikan rasa puas pada konsumen. Terciptanya kepuasan konsumen akan menciptakan hubungan yang harmonis antara perusahaan dan konsumen, terciptanya pembelian ulang, loyalitas konsumen, sertaterbentuknya rekomendasi dari mulut ke mulut oleh konsumen yang menguntungkan bagi perusahaan (Efendi dan Kastawan, 2018). Oleh karena itu, kepuasan konsumen sangat penting untuk diperhatikan oleh perusahaan dalam persaingan bisnis.

Kepuasan yang dimaksud adalah perasaan senang atau kecewa seseorang yang muncul setelah membandingkan kinerja produk atau jasa yang dipikirkan terhadap kinerja yang diharapkan (Kotler dan Keller, 2009 : 138-139). Jika kinerja produk atau jasa yang diberikan oleh perusahaan lebih rendah dari harapan konsumen maka konsumen akan tidak puas dan kecewa. Sebaliknya, jika kinerja produk atau jasa yang diberikan lebih tinggi dari harapan konsumen, konsumen tersebut akan merasa gembira dan sangat puas. Oleh karena itu, untuk membuat konsumen menjadi gembira dan merasa puas, perusahaan harus memberikan produk dan juga kualitas pelayanan yang baik. Hasil penelitian oleh Bakti dan Sumaedi (2012), Faradina danSatrio (2016), Allan (2016), serta Wiharyo dan Budiarti (2017) menunjukan kualitas pelayanan berpengaruh positif signifikan 
terhadap kepuasan konsumen. Dengan kata lain kualitas pelayanan yang baik akan memberikan kepuasan bagi konsumen, sedangkan kualitas pelayanan yang buruk akan membuat kecewa dan ketidakpuasan konsumen.

Menurut Tjiptono (2001: 267), kualitas pelayanan atau service qualityadalah upaya memenuhi kebutuhan dan keinginan konsumen serta ketepatan penyampaiannya untuk mengimbangi harapan konsumen. Untuk memberikan pelayanan yang berkualitas, perusahaan dapat memperhatikan 5 indikator dari kualitas pelayanan yaitu tangibles atau bukti fisik, empathy atau perhatian, responsivenessatau daya tanggap, reliability atau keandalan, dan assurance atau jaminan. Pada penelitian Kampakaki dan Papathanasiou (2016) dimensi pelayanan yang paling berkontribusi dalam kepuasan konsumen adalah assurance dan reliability. Sedangkan pada penelitian Prasojo dan Wahyuati (2016) dimensi responsiveness merupakan dimensi pelayanan yang paling dominan dalam kepuasan konsumen.

Namun yang menjadi masalah dalam memberikan kepuasan konsumen adalah kepuasan konsumen tidak terbatas dan selalu berubah-ubah sehingga kualitas pelayanan yang sesuai dengan standart yang di terapkan pun sering kali kurang di mata konsumen, sehingga konsumen merasa kurang puas dengan kinerja produk ataupun jasa yang diberikan. Konsumen sebagai pihak pertama jasa tentu saja akan dapat menilai kualitas pelayanan yang di berikan oleh perusahaan. Untuk itu perusahaan membutuhkan umpan balik dari pandangan konsumen yang dilakukan sebagai masukan dalam melakukan perbaikanperbaikan pelayanan dan fasilitas, agar dapat memberikan kualitas pelayanan yang 
I Gede Bayu Mertha Segara,Peran Kualitas Pelayanan...

maksimal kepada konsumen. Salah satu upaya peningkatan kualitas pelayanan adalah dengan menerapkan konsep dasar total quality management (TQM).

TQM merupakan salah satu strategi organisasi yang digunakan untuk memperbaiki kepuasan konsumen dengan mengembangkan prosedur dan mengelola kualitas hasil (Ratnaningrum dan Nasron, 2013). Proses TQM sangat berkaitan dengan konsumen karena proses TQM bermula dari konsumen dan berakhir pula pada konsumen. Keinginan, kebutuhan, dan harapan konsumen yang menjadi input diproses dalam organisasi untuk diproduksi menjadi barang atau jasa yang pada akhirnya akan memberikan kepuasan kepada konsumen sebagai output nya (Ekoanindiyo, 2010). TQM merupakan suatu pendekatan dalam menjalankan usaha yang mencoba untuk memaksimumkan daya saing organisasi melalui perbaikan terus menerus atas produk, tenaga kerja, proses, dan lingkungannya ( Tjiptono dan Diana, 2001 : 4).

Tujuan utama total quality management adalah perbaikan mutu pelayanan secara terus-menerus (Ekoanindiyo, 2010). Tujuan lainnya adalah memberikan kepuasan konsumen. Mekanismememahami konsumen dimulai dengan menampung keluhan, menganalisis penjualan dan mendapat umpan balik dari konsumen, serta wawancara pribadi dengan konsumen. Pemahaman terhadap harapan konsumen adalah prasyarat untuk meningkatan kualitas dan mencapai kepuasan total konsumen.

Total quality management akan memberikan dampak positif pada seluruh elemen di tempat kerja, selain itu pekerjaan akan menjadi terarah yang mengakibatkan karyawan sebagai pelaku merasakan kenyamanan dengan 
keteraturan tersebut. Penelitian yang dilakukan oleh Zjulla (2015) menyimpulkan bahwa penerapan total quality management (TQM) mempengaruhi peningkatan kepuasan pengguna terhadap kualitas layanan perpustakaan di perguruan tinggi. Hal ini didukung juga oleh penelitian Andre dan Tjun (2014), Chen et al. (2014), Mercy dan Taiye (2015), Chiguvi (2016),Elan dan Kusmindah (2016), Alfalah (2017) serta Islami dan Sudaryanto (2017), dan lebih jelas dibuktikan oleh penelitian Sakthivel et al. (2005) yaitu terdapat korelasi positif yang signifikan antara lima variabel total qualitymanagement yaitu komitmen manajemen puncak, penyampaian pengajaran, fasilitas, kesopanan, dan umpan balik konsumen dan perbaikan terhadap kepuasansiswa. total quality management pada akhirnya akan memberikan dampak yang sangat baik bagi perusahaaan, “..having a quality management system in place has led to increases in customers, profit and customer satisfaction." (Alvarez et al. 2012)

Penelitian terdahulu yang berhubungan dengan penelitian ini adalah penelitian dari Ooiet al. (2011) tentang apakah penerapan praktek TQM mendukung kepuasan konsumen dan kualitas pelayanan. Hasil dari penelitian tersebut menunjukkan bahwa hanya tiga dari enam dimensi penerapan total quality management yaitu kepemimpinan, fokus konsumen dan analisis informasi memiliki pengaruh yang signifikan terhadap kepuasan konsumen. Pada sisi lain fokus konsumen dan analisis informasi berpengaruh terhadap kualitas pelayanan. PenelitianOoiet al. (2011) menggunakan variabel kualitas pelayanan sebagai variabel endogen atau variabel yang hanya bisa dipengaruhi oleh variabel lainnya, sedangkan pada penelitian sekarang ini variabel kualitas pelayanan berperan 
I Gede Bayu Mertha Segara,Peran Kualitas Pelayanan...

sebagai variabel mediasi yaitu variabel yang memberikan pengaruh tidak langsung variabel independen terhadap variabel dependen (Sugiyono dalam Utama, 2016 : 160). Hal ini karena dalam penelitian Pranandya (2013) mengungkapkan bahwa total quality management mempunyai hubungan negatif yang tidak signifikan terhadap kepuasan konsumen.

Semakin sering dilakukan perbaikan kualitas secara terus menerus akan menimbulkan biaya yang tinggi yang tentu biaya tersebut akan dilimpahkan kepada konsumen melalui harga yang harus dibayarkan oleh konsumen. Hal ini menyebabkan konsumen merasa diberatkan dan kepuasan konsumen akan menurun. Memberikan kualitas pelayanan membantu menyamarkan peningkatan biaya yang harus dikeluarkan konsumen karena salah satu manfaat menciptakan kualitas pelayanan adalah konsumen tidak akan mempermasalahkan mengenai harga.

Konsumen akan bersedia membayar berapapun ketika perusahaan mampu memberikan kualitas pelayanan yang sesuai kebutuhan konsumen sehinnga konsumen tersebut percaya terhadap perusahaan dan pada akhirnya kualitas pelayanan akan menyebabkan kepuasan konsumen, oleh karena itu kualitas pelayanan digunakan sebagai variabel mediasi hubungan TQM dengan kepuasan konsumen. Hal ini didukung oleh beberapa penelitian sebelumnya seperti penelitiaan yang dilakukan oleh Faradina dan Satrio (2016), Allan (2016), Ashima (2017), serta Wiharyo dan Budiarti (2017) yang menyatakan bahwa kualitas pelayanan berpengaruh positif dan signifikan terhadap kepuasan konsumen. Sedangkan untuk menciptakan kualitas pelayanan yang baik 
diperlukan penerapan total quality management yang baik oleh manajeman. Didukung oleh penelitian Suhermini (2010), Pranandya (2013)Andre dan Tjun (2014) serta Hartantyo dan Hendayani (2015) yang menyimpulkanpenerapan total quality management (TQM) mempunyai hubungan signifikan dan positif terhadap kualitas pelayanan. Penelitian lain yang mendukung penggunaan variabel kualitas pelayanan sebagai variabel mediasi adalah penelitian dari Pranandya (2013), Alfalah (2017), dan Priyanto (2017) yang menyatakan bahwa terdapat pengaruh kualitas pelayanan sebagai variabel mediasi pada hubungan total quality management terhadap kepuasan konsumen. Oleh karena itu akan diteliti kembali peran kualitas pelayanan dalam memediasi hubungan penerapan TQM terhadap kepuasan konsumen di Sepeda Bali Tour.

Sepeda Bali Tour adalah salah satu perusahaan jasa tur yang menyediakan jasa tur dengan mengunakan sepeda. Jasa tur ini adalah sebuah paket perjalanan yang memadukan perjalanan tur mengunjungi tempat-tempat wisata kemudian menikmati suasana pedesaan Bali dengan menggunakan sepeda sebagai jasa utama yang diberikan. Struktur organisasi dari Sepeda Bali Tour cukup sederhana, yaitu seorang manajer sekaligus pemilik, dan bawahan yang terdiri dari pemandu, tukang masak, supir dan karyawan. Berdasarkan wawancara yang sudah dilakukan, konsumen dari jasa tur ini adalah wisatawan lokal dan wisatawan asing namun kebanyakan adalah wisatawan asing. Manajer Sepeda Bali Tour kemudian mengungkapkan masalah yang sering dihadapi oleh Sepeda Bali Tour adalah ketika wisatawan yang mengikuti tur ini berjumlah lebih dari 10 orang. Terbatasnnya pemandu, menyebabkan perusahaan memperkerjakan karyawan 
I Gede Bayu Mertha Segara,Peran Kualitas Pelayanan...

yang tidak fasih berbahasa inggris sebagai pemandu untuk sementara agar menyeimbangkan jumlah pemandu dengan jumlah wisatawan. Tentu risikonya dalam berkomunikasi antara wisatawan dan pemandu tidak maksimal. Hal ini memperlihatkan bahwa perusahaaan belum berhasil menerapkan total quality management dengan baik, karena menurut Santosa ( Tjiptono dan Diana, 2001 : 4) total quality management mampu mengangkat kualitas sebagai strategi usaha yang berorientasi pada kepuasan konsumen dengan melibatkan seluruh anggota organisasi.

Total quality management merupakan suatu sistem yang berfokus pada orang, sehingga orang yang terlibat didalamnya harus mengawasi kualitas, sehingga terbatasnya kemampuan karyawan Sepeda Bali Tour adalah suatu penurunan kualitas yang diberikan kepada konsumen. Untuk mengantisipasi hal tersebut terus berulang, pemilik Sepeda Bali Tour mengungkapkan sudah melakukan pelatihan berbahasa inggris kepada karyawannya, namun hasilnya belum maksimal. Selain itu keterbatasan dalam fasillitas sepeda yang dimiliki oleh Sepeda Bali Tour, menyebabkan perusahaan harus menyewa sepeda di tempat lain dengan risiko kualitas sepeda tidak maksimal. Manajer Sepeda Bali Tour sangat merasakan banyaknya kekurangan internal yang ada pada bisnisnya, namun selama pemberian pelayanan kepada konsumennya, keluhan dari konsumen tentang Sepeda Bali Tour tidak terlalu sering diungkapkan oleh konsumennya, konsumen masih mendapatkan kepuasan dari penggunaan jasa tur ini dan tidak jarang konsumen memberikan komentar yang positif di situs-situs travel. 


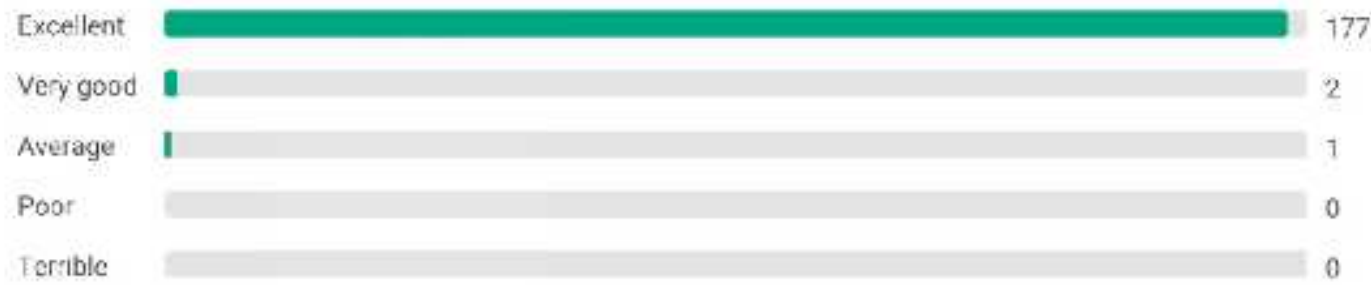

\section{Gambar 1. Penilaian Konsumen terhadap Sepeda Bali Tour}

Sumber :Tripadvisor, 2018

Hal tersebutlah yang menjadi alasan, perusahaan ini digunakan sebagai lokasi penelitian, karena adanya pertimpangan antara penerapan TQM dengan jumlah wisatawan yang datang menggunakan jasa ini.

Tujuan dari penelitian ini adalah untuk mengetahui bagaimana pengaruh penerapan TQM terhadap kualitas pelayanan, pengaruh penerapan TQM terhadap kepuasan konsumen, pengaruh kualitas pelayanan terhadap kepuasan konsumen dan bagaimana peran kualitas pelayanan memediasi pengaruh penerapan TQM terhadap kepuasan konsumen di Sepeda Bali Tour. Diharapkan penelitian dapat memberikan manfaat bagi perusahaan, dan bahan sebagai rujukan untuk penelitian selanjutnya.

Menurut Tjiptono dan Diana (2001:4), total quality management mencoba memaksimalkan daya saing yang dimiliki organisasi dengan melakukan perbaikan produk, jasa, manusia, proses, dan lingkungannya secara terus - menerus.Menurut Goetsch dan Davis (Tjiptono dan Diana, 2001 : 15) fokus pada pelanggan, obsesi terhadap kualitas, pendekatan ilmiah, komitmen jangka panjang, kerjasama tim (teamwork), perbaikan sistem secara berkesinambungan, pendidikan dan 
I Gede Bayu Mertha Segara,Peran Kualitas Pelayanan...

pelatihan, kebebasan yang terkendali, kesatuan tujuan, dan adanya keterlibatan dan pemberdayaan karyawan merupakan karakteristik dari total quality management, dimanatujuan akhirnya adalah mencapai keunggulan bersaing dengan perbaikan mutu yang berkesinambungan.

Menurut Kotler (2001 : 25), kualitas pelayanan merupakan kemampuan untuk memuaskan kebutuhan konsumen dari bentuk karakteristik barang dan jasa yang didefinisikan sebagai hasil perbandingan antara kinerja pelayanan dan harapan dari pelanggan. Karakteristik tersebut menurut Zeithaml, Berry, dan Parasuraman (Tjiptono dan Diana, 2001 : 27-28) meliputi : bukti langsung (tangibles), empati (empathy), kehandalan (reliability), daya tanggap (responsiveness), jaminan (assurance).

Kepuasan menurut Kotler dan Keller (2009 : 138) yaitu perasaan senang atau kecewa seseorang akibatperbandingan kinerja produk yang didapat konsumendengan harapan yang diinginkan olehkonsumen. Kepuasan konsumen bermanfaat bagi perusahaan untuk terciptanya hubungan harmonis antara perusahaan dan konsumen, terciptanya pembelian ulang, loyalitas konsumen, rekomendasi dari mulut ke mulut (word of mouth), menjaga reputasi perusahaan, serta peningkatan laba perusahaan(Tjiptono, $2001: 102)$

Total quality management tidak hanya terbatas pada kinerja kualitas produk tetapi juga mencakup aspek sektor jasa yaitu kualitas pelayanan guna meningkatkan produktivitas dan peningkatan kinerja organisasi. Menurut penelitian Kersten (2009), Suhermini (2010), Pranandya (2013), Andre dan Tjun (2014)serta Miartana et al. (2014) yang menyimpulkan bahwa total quality 
management berpengaruh positif dan signifikan terhadap kualitas layanan, makadikembangan hipotesis pertama yaitu penerapan total quality management berpengaruh positif signifikan terhadap kualitas pelayanan.

Hipotesis kedua yaitu penerapan total quality management berpengaruh positif signifikan terhadap kepuasan konsumen dikembangkan dengan melihat keterkaitan dan perhatian total quality management terhadaporientasi pelanggan yang memberikan dampak yang paling besar dalam implementasinya.Selain itu, dengan dukungan hasil penelitian terdahulu seperti penelitian Sakthivel et al. (2005),Andre dan Tjun (2014), Chen et al. (2014), Mercy dan Taiye (2015), Chiguvi (2016) ),Elan dan Kusmindah (2016),Alfalah (2017) serta Islami dan Sudaryanto (2017) yang menyatakan total quality management berpengaruh positif signifikan terhadap kepuasan konsumen.

Hipotesis ketiga yaitu kualitas pelayanan berpengaruh positif signifikan terhadap kepuasan konsumen dikembangkan dengan adanya keterkaitankualitas pelayanan yang merupakan salah satu tolak ukur mengapa konsumen puas, dengan kata lain baiknya kualitas pelayanan akan memberikan kepuasan, sebaliknya buruknya kualitas pelayanan akan mengecewakan dan menimbulkan ketidakpuasan konsumen. Hasil penelitian olehMosahab, Mahamad, dan Ramayah (2010), Bakti dan Sumaedi (2012), Pranandya (2013),Faradina danSatrio (2016), Allan (2016), serta Wiharyo dan Budiarti (2017) juga menunjukanhasil bahwa kualitas pelayanan berpengaruh positif signifikan terhadap kepuasan pelanggan.

Hipotesis yang terakhir yaitu kualitas pelayanan berperan positif dalam memediasi pengaruh penerapantotal quality management terhadap kepuasan 
I Gede Bayu Mertha Segara,Peran Kualitas Pelayanan...

konsumen dikembangkan karena adanya hubungan negatif yang tidak signifikan antara total quality management terhadap kepuasan konsumen (Pranandya (2013). Semakin sering dilakukan perbaikan kualitas secara terus menerus akan menimbulkan biaya yang tinggi yang tentu biaya tersebut akan dilimpahkan kepada konsumen melalui harga yang harus dibayarkan oleh konsumen. Hal ini menyebabkan konsumen merasa diberatkan dan kepuasan konsumen akan menurun. Disisi lain penerapan total quality management akan berdampak pada perbaikan kualitas pelayanan, dengan kualitas pelayanan yang baik akan memberikan peningkatan kepuasan konsumen. Oleh karena itu secara tidak langsung kualitas pelayanan berperan sebagai mediasi hubungan antara total quality management dengan kepuasan konsumen. Hal ini didukung oleh penelitian Pranandya (2013),Priyanto (2017) dan Alfalah (2017)

\section{METODE PENELITIAN}

Penelitian ini merupakan penelitian asosiatif dengan pendekatan kuantitatif untuk menjelaskan peran kualitas pelayanan sebagai variabel mediasi pengaruh penerapan total quality management terhadap kepuasan konsumen di perusahaan jasa Sepeda Bali Tour. Penentuan sampel mengggunakan teknik purposive sampling dengan jumlah sampel sebanyak 200 konsumen Sepeda Bali Tour. Jumlah sampel tersebut diambil berdasarkan jumlah indikator yang digunakan pada penelitian ini yang dikalikan dengan lima hingga sepuluh (Sugiyono, 2014:117). Pada penelitian ini digunakan 34 indikator yang terdiri dari 10 indikator total quality management, 15 indikator kualitas pelayanan serta 9 indikator kepuasan konsumen, sehingga sampel minimalnya yaitu 36 indikator x 5 
$=170$, sedangkan maksimal sampelnya yaitu 36 indikator x $10=340$, maka sampel yang digunakan harus diantara itu, yaitu 200 sampel konsumen Sepeda Bali Tour.

Data diambil dengan metode wawancara, observasi dan survey dengan kuisioner yang diberikan skala likert 1-5 pada setiap indikator yang digunakan.Sebelum diolah, validitas dan reliabilitas instrumen penelitian di uji terlebih dahulu, dimanajika koefisien korelasi suatu variabel diatas 0,30 variabel tersebut dikatakan valid (Sugiyono, 2014:148), sedangkan jika nilai Cronbach Alpha $(\alpha)>0,60$ variabel dikatakan reliabel (Ghozali, 2013:47).

Selanjutnya data diolah dengan menggunakan teknik path analysis dan uji sobel. Analisis jalur (path analysis) adalah perluasan penerapan analisis regresi linier berganda untuk memprediksi hubungan kausalitas antar variabel.

Persamaan sub-struktural 1:

$$
\mathrm{Y}_{1}=\beta_{1} \mathrm{X}+\varepsilon_{1}
$$

Persamaan sub-struktural 2:

$$
Y_{2}=\beta_{2} X+\beta_{3} Y_{1}+\varepsilon_{2}
$$

Sedangkan Uji Sobel dilakukan dengan menguji kekuatan pengaruh tidak langsung variabel total quality management (X) terhadap variabel kepuasan konsumen $\left(\mathrm{Y}_{2}\right)$ melalui variabel kualitas pelayanan $\left(\mathrm{Y}_{1}\right) . \mathrm{Uji}$ Sobel dihitung dengan rumus :

$$
Z=\frac{a}{\sqrt{b^{2} s_{u}^{2}+u^{2} s_{b}^{2}+s_{u}^{2} s_{b}^{2}}}
$$


Keterangan :

a $\quad=$ koefisien regresi dari variabel bebas terhadap variabel mediasi

$\mathrm{S}_{\mathrm{a}} \quad=$ standar eror dari a

$\mathrm{b} \quad=$ koefisien regresi dari variabel mediasi terhadap variabel dependen

$\mathrm{S}_{\mathrm{b}} \quad=$ standar eror dari $\mathrm{b}$

\section{HASIL DAN PEMBAHASAN}

Responden yang diamati meliputi usia dan jenis kelamin dengan kriteria sudah pernah menggunakan jasa Sepeda Bali Tour.

Tabel 1.

Profil Responden

\begin{tabular}{ccccc}
\hline No & Variabel & Klasifikasi & Jumlah (orang) & Persentase (\%) \\
\hline \multirow{3}{*}{1} & & $18-30$ & 71 & 36 \\
& \multirow{2}{*}{ Usia (tahun) } & $31-50$ & 76 & 38 \\
& & $>50$ & 53 & 27 \\
\hline & Jumlah & & $\mathbf{2 0 0}$ & $\mathbf{1 0 0}$ \\
\hline \multirow{2}{*}{2} & \multirow{2}{*}{ Jenis kelamin } & Laki - laki & 85 & 42 \\
& Jumlah & Perempun & 115 & 58 \\
\hline & & $\mathbf{2 0 0}$ & $\mathbf{1 0 0}$ \\
\hline
\end{tabular}

Sumber : Data diolah, 2018

Tabel 1 menunjukan bahwa selisih jumlah antara klasifikasi variabel usia dan jenis kelamin tidak terlalu signifikan. Hal ini memperlihatkan bahwa Sepeda Bali Tour diminati oleh semua kalangan, baik anak muda, orang tua, laki-laki, maupun perempuan, dimana sebagian besar merupakan kelompok keluarga maupun pasangan-pasangan yang ingin menghabiskan liburan mereka di Bali.

Dari sepuluh karakteristik total quality management penelitian ini hanya menggunakan indikator yang memuat tiga variabel TQM meliputi: fokus pada konsumen, obsesi terhadap kualitas dan kerjasama tim (teamwork). 
Tabel 2.

Hasil Uji Validitas variabel Total Quality Management $(\mathbf{X})$

\begin{tabular}{|c|c|c|c|c|}
\hline $\begin{array}{l}\mathbf{N} \\
\mathbf{0}\end{array}$ & Variabel & Indikator & $\begin{array}{c}\text { Koefisien } \\
\text { Korelasi }\end{array}$ & Keterangan \\
\hline \multirow{13}{*}{1} & \multirow{13}{*}{$\begin{array}{l}\text { Total Quality } \\
\text { Management }\end{array}$} & Fokus Pelanggan & & \\
\hline & & $\begin{array}{l}\text { Interaksi Karyawan saat melayani konsumen } \\
(\mathrm{x} 1.1)\end{array}$ & 0.806 & Valid \\
\hline & & $\begin{array}{c}\text { Interaksi karyawan saat memberikan } \\
\text { informasi (x1.2) }\end{array}$ & 0.698 & Valid \\
\hline & & $\begin{array}{l}\text { Interaksi karyawan saat konsumen memberi } \\
\text { pertanyaan }(\mathrm{x} 1.3)\end{array}$ & 0.76 & Valid \\
\hline & & $\begin{array}{c}\text { kesempataan menyampaikan pertanyaan dan } \\
\text { keluhan }(\mathrm{x} 1.4)\end{array}$ & 0.635 & Valid \\
\hline & & Obsesi terhadap Kualitas & & \\
\hline & & Kualitas pelayanan yang diberikan (x2.1) & 0.816 & Valid \\
\hline & & Ketepatan wkatu Kerja (x2.2) & 0.486 & Valid \\
\hline & & Ketelitian pemberian pelayanan $(\mathrm{x} 2.3)$ & 0.513 & Valid \\
\hline & & Kerjasama Tim & & \\
\hline & & $\begin{array}{c}\text { Keseragaaman Jawaban yang diberikan } \\
\text { kepada konsumen (x3.1) }\end{array}$ & 0.532 & Valid \\
\hline & & Kerjasama yang baik antara karyawan (x3.2) & 0.6 & Valid \\
\hline & & Terjalin Keakraban antara karyawan (x3.3) & 0.612 & Valid \\
\hline
\end{tabular}

Sumber : data diolah, 2018

Berdasarkan hasil olah data pada Tabel 2, nilai koefisien korelasi masingmasing indikator kepuasan konsumen menunjukkan nilai yang lebih besar dari 0,3 ( $\mathrm{r} \geq 0,3$ ), berarti bahwa semua instrumen total quality management yang digunakan adalah valid.

Berdasarkan hasil olah data pada Tabel 3, nilai koefisien korelasi masingmasing indikator kepuasan konsumen menunjukkan nilai yang lebih besar dari 0,3 ( $\mathrm{r} \geq 0,3)$, berarti bahwa semua instrumen kualitas pelayanan adalah valid.

Tabel 3.

Hasil Uji Validitas variabel Kualitas Pelayanan $\left(\mathbf{Y}_{1}\right)$

\begin{tabular}{ccccc}
\hline $\begin{array}{c}\text { N } \\
\text { o }\end{array}$ & Variabel & Indikator & $\begin{array}{c}\text { Koefisien } \\
\text { Korelasi }\end{array}$ & Keterangan \\
\hline 1 & Kualitas & Tangibles $\left(\mathbf{Y}_{1.1}\right)$ & & \\
1 & Pelayanan & Lingkuangan sekitar trek bersepeda & 0.519 & Valid \\
\hline
\end{tabular}


I Gede Bayu Mertha Segara,Peran Kualitas Pelayanan...

\begin{tabular}{|c|c|c|}
\hline \multicolumn{3}{|l|}{$\left(\mathrm{Y}_{1.1 .1}\right)$} \\
\hline Kondisi sepeda yang digunakan $\left(\mathrm{Y}_{1.1 .2}\right)$ & 0.632 & Valid \\
\hline Penampilan karyawan $\left(\mathrm{Y}_{1.1 .3}\right)$ & 0.383 & Valid \\
\hline Kebersihan makanan $\left(\mathrm{Y}_{1.1 .4}\right)$ & 0.913 & Valid \\
\hline Suasanan tempat makan $\left(\mathrm{Y}_{1.1 .5}\right)$ & 0.688 & Valid \\
\hline kebersihan toilet $\left(\mathrm{Y}_{1.1 .6}\right)$ & 0.795 & Valid \\
\hline \multicolumn{3}{|l|}{$\operatorname{Empati}\left(\mathbf{Y}_{1.2}\right)$} \\
\hline Keramahan Karyawan $\left(\mathrm{Y}_{1.2 .1}\right)$ & 0.692 & Valid \\
\hline Perhatian Karyawan $\left(\mathrm{Y}_{1.2 .2}\right)$ & 0.832 & Valid \\
\hline \multicolumn{3}{|l|}{$\operatorname{Kehandalan}\left(\mathbf{Y}_{1.3}\right)$} \\
\hline Penanganan Masalah $\left(\mathrm{Y}_{1.3 .1}\right)$ & 0.832 & Valid \\
\hline Pemberian Informasi $\left(\mathrm{Y}_{1.3 .2}\right)$ & 0.832 & Valid \\
\hline Professionalitas karyawan $\left(\mathrm{Y}_{1.3 .3}\right)$ & 0.832 & Valid \\
\hline \multicolumn{3}{|l|}{ Daya Tanggap $\left(\mathbf{Y}_{1.4}\right)$} \\
\hline $\begin{array}{l}\text { Memahami kebutuhan konsumen } \\
\left(\mathrm{Y}_{1.4 .1}\right)\end{array}$ & 0.913 & Valid \\
\hline Menangani keluhan konsumen $\left(\mathrm{Y}_{1.4 .2}\right)$ & 0.775 & Valid \\
\hline \multicolumn{3}{|l|}{$\operatorname{Jaminan}\left(\mathbf{Y}_{1.5}\right)$} \\
\hline $\begin{array}{c}\text { Konsumen Percaya kepada karyawan } \\
\left(\mathrm{Y}_{1.5 .1}\right)\end{array}$ & 0.922 & Valid \\
\hline konsumen mendapat rasa aman $\left(\mathrm{Y}_{1.5 .2}\right)$ & 0.853 & Valid \\
\hline
\end{tabular}

Berdasarkan hasil olah data pada Tabel 4, nilai koefisien korelasi masingmasing indikator kepuasan konsumen menunjukkan nilai yang lebih besar dari 0,3 ( $\mathrm{r} \geq 0,3)$, berarti bahwa semua instrumen kepuasan konsumen adalah valid.

Tabel 5. menunjukkan bahwa seluruh variabel yang digunakan dalam penelitian ini telah mampu memenuhi syarat konsistensi maupun keandalan data. Keseluruhan variabel dapat dilihat memiliki nilai cronbach alpha yang lebih besar dari 0,6 maka dapat disimpulkan bahwa seluruh indikator variabel dalam penelitian ini adalah reliabel, sehingga dapat digunakan sebagai instrumen penelitian.

Tabel 4.

Hasil Uji Validitas Variabel Kapuasan Konsumen $\left(\mathbf{Y}_{2}\right)$

\begin{tabular}{lllll}
\hline $\mathbf{N}$ & Variabel & Indikator & Koefisien & Keterangan \\
\hline
\end{tabular}




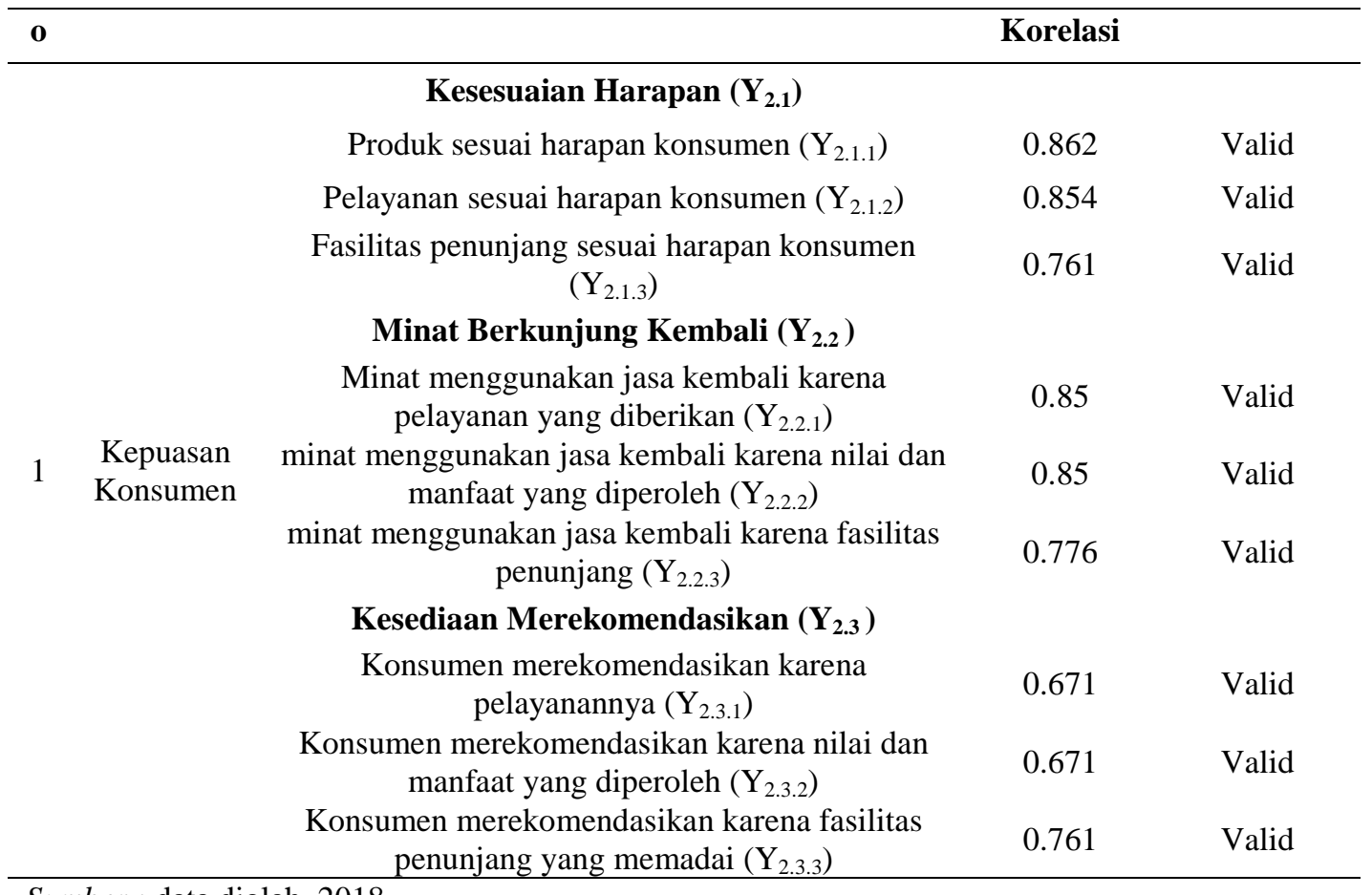

Sumber : data diolah, 2018

Tabel 5.

Hasil Uji Reliabilitas

\begin{tabular}{cccc}
\hline No & Variabel & Cronbach alpha & Keterangan \\
\hline 1 & Total Quality management & 0.825 & Reliabel \\
2 & Kualitas Pelayanan & 0.937 & Reliabel \\
3 & Kepuasan Konsumen & 0.919 & Reliabel \\
\hline
\end{tabular}

Sumber : data diolah, 2018

Teknik analisis jalur atau path analysis digunakan dalam pengujian data penelitian ini, dimana teknik ini adalah perluasan dari analisis regresi berganda untuk menguji hubungan kausalitas antara dua atau lebih variabel. Tahapan untuk melakukan pengujian data dengan analisis jalur atau path analysis adalah sebagai berikut.

Tabel 6.

Hasil Analisis Jalur (Regresi Substruktural 1) X terhadap $\mathrm{Y}_{1}$

\begin{tabular}{|c|c|c|c|c|}
\hline \multirow[t]{2}{*}{ Model } & Unstandardized Coefficients & $\begin{array}{c}\text { Standardized } \\
\text { Coefficients }\end{array}$ & $\mathbf{T}$ & Sig. \\
\hline & Std. Error & Beta & & \\
\hline
\end{tabular}




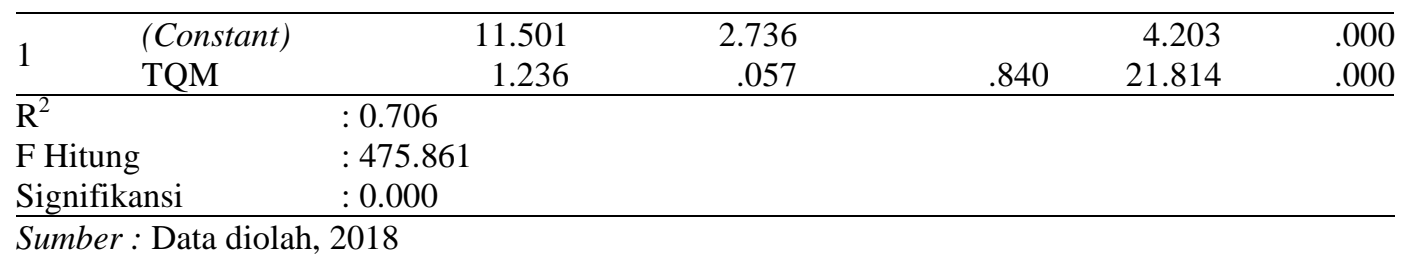

Persamaan struktural berdasarkan hasil analisis jalur substruktal 1 pada tabel 6yaitu :

$$
\begin{aligned}
& Y_{1}=\beta_{1} X+\varepsilon_{1} \\
& Y_{1}=0,840 X+\varepsilon_{1}
\end{aligned}
$$

Nilai $\beta_{1}$ sebesar 0,840 menunjukan bahwa total quality management (tqm) berpengaruh positif terhadap kualitas pelayanan.

Tabel 7.

\begin{tabular}{|c|c|c|c|c|c|c|}
\hline & \multirow[t]{2}{*}{ Model } & \multicolumn{2}{|c|}{ Unstandardized Coefficients } & \multirow{2}{*}{$\begin{array}{c}\begin{array}{c}\text { Standardized } \\
\text { Coefficients }\end{array} \\
\text { Beta } \\
\end{array}$} & \multirow[t]{2}{*}{$\mathbf{T}$} & \multirow[t]{2}{*}{ Sig. } \\
\hline & & B & Std. Error & & & \\
\hline \multirow{3}{*}{1} & (Constant) & 2.556 & 1.136 & & 2.250 & .026 \\
\hline & TQM & .334 & .042 & .386 & 8.044 & .000 \\
\hline & Kualitas_Pelayanan & .343 & .028 & .582 & 12.122 & .000 \\
\hline $\mathrm{R}$ & & $: 0.866$ & & & & \\
\hline & stik & : 639.031 & & & & \\
\hline & kansi & $: 0.000$ & & & & \\
\hline
\end{tabular}

Hasil Analisis Jalur (Regresi Substruktural 2) $X$ dan $Y_{1}$ terhadap $Y_{2}$

Persamaan struktural berdasarkan hasil analisis jalur substruktal 2 pada tabel

7, yaitu :

$$
\begin{aligned}
& Y_{2}=\beta_{2} X+\beta_{3} Y_{1}+\varepsilon_{2} \\
& Y_{2}=0,386 X+0.582 Z+\varepsilon_{2}
\end{aligned}
$$

Nilai $\beta_{2}$ sebesar 0,386 menunjukan bahwa total quality management (tqm) memiliki pengaruh positif terhadap kepuasan konsumen. Sedangkan nilai $\beta_{3}$ sebesar 0,582 memiliki arti bahwa kualitas pelayanan berpengaruh positif terhadap kepuasan konsumen adalah sebagai berikut: Pengaruh variabel total 
quality management $(\mathrm{X})$ terhadap kualitas pelayanan $\left(\mathrm{Y}_{1}\right), \beta_{1}=0,840$, Pengaruh variabel total quality management $(\mathrm{X})$ terhadap kepuasan konsumen $(\mathrm{Y}), \beta_{2}=$ 0,386, Pengaruh variabel kualitas pelayanan $\left(\mathrm{Y}_{1}\right)$ terhadap kepuasan konsumen $\left(\mathrm{Y}_{2}\right), \quad \beta_{3}=0,582$, Pengaruh variabel total quality management $(\mathrm{X})$ terhadap kepuasan konsumen $\left(\mathrm{Y}_{2}\right)$ dengan kualitas pelayanan sebagai variabel mediasi :

Indirect effect $=\beta_{1} \times \beta_{3}$.

$$
\begin{aligned}
& =0,840 \times 0,582 \\
& =0,489
\end{aligned}
$$

Total pengaruh variabel total quality management $(\mathrm{X})$ terhadap kepuasan konsumen $\left(\mathrm{Y}_{2}\right)$ melalui variabel kualitas pelayanan $\left(\mathrm{Y}_{1}\right)$ adalah sebagai berikut :

Total effect $\quad=\beta_{2}+\left(\beta_{1} \times \beta_{3}\right)$

$$
\begin{aligned}
& =0,386+(0,840 \times 0,582) \\
& =0,878
\end{aligned}
$$

Nilai koefisien determinasi $\left(\mathrm{R}^{2}\right)$ dan variabel error (e)

$$
\begin{aligned}
& \mathrm{e}=\sqrt{1-\mathrm{R}^{2}} \ldots \ldots \ldots \ldots \ldots \ldots \ldots \ldots \ldots \ldots \ldots \ldots \ldots \ldots \\
& \mathrm{e}_{1}=\sqrt{1-\mathrm{R}_{1}^{2}}=\sqrt{1-0,706}=0,542 \\
& \mathrm{e}_{2}=\sqrt{1-\mathrm{R}_{2}^{2}}=\sqrt{1-0,866}=0,366
\end{aligned}
$$

Berdasarkan nilai variabel error yang didapat, dapat dihitung koefisien determinasi total sebagai berikut :

$$
\begin{aligned}
& \mathrm{R}_{\mathrm{mI}}^{2}=1-\left(\mathrm{e}_{1}\right)^{2}\left(\mathrm{e}_{2}\right)^{2} \ldots \ldots \ldots \ldots \ldots \ldots \ldots \ldots \ldots \ldots \ldots \ldots \ldots \ldots \ldots \ldots \\
&=1-(0,542)^{2}(0,366)^{2} \\
&=1-(0,294)(0,134)=1-0,039 \\
&=0,961
\end{aligned}
$$


Nilai $\mathrm{R}_{\mathrm{II}}^{2}$ sebesar 0,961 berarti variasi kepuasan konsumen dipengaruhi oleh 96,1 persen variasi total quality management dan kualitas pelayanan, sedangkan sebesar 3,9 persen dipengaruhi oleh variabel lain yang tidak dimasukan kedalam model.

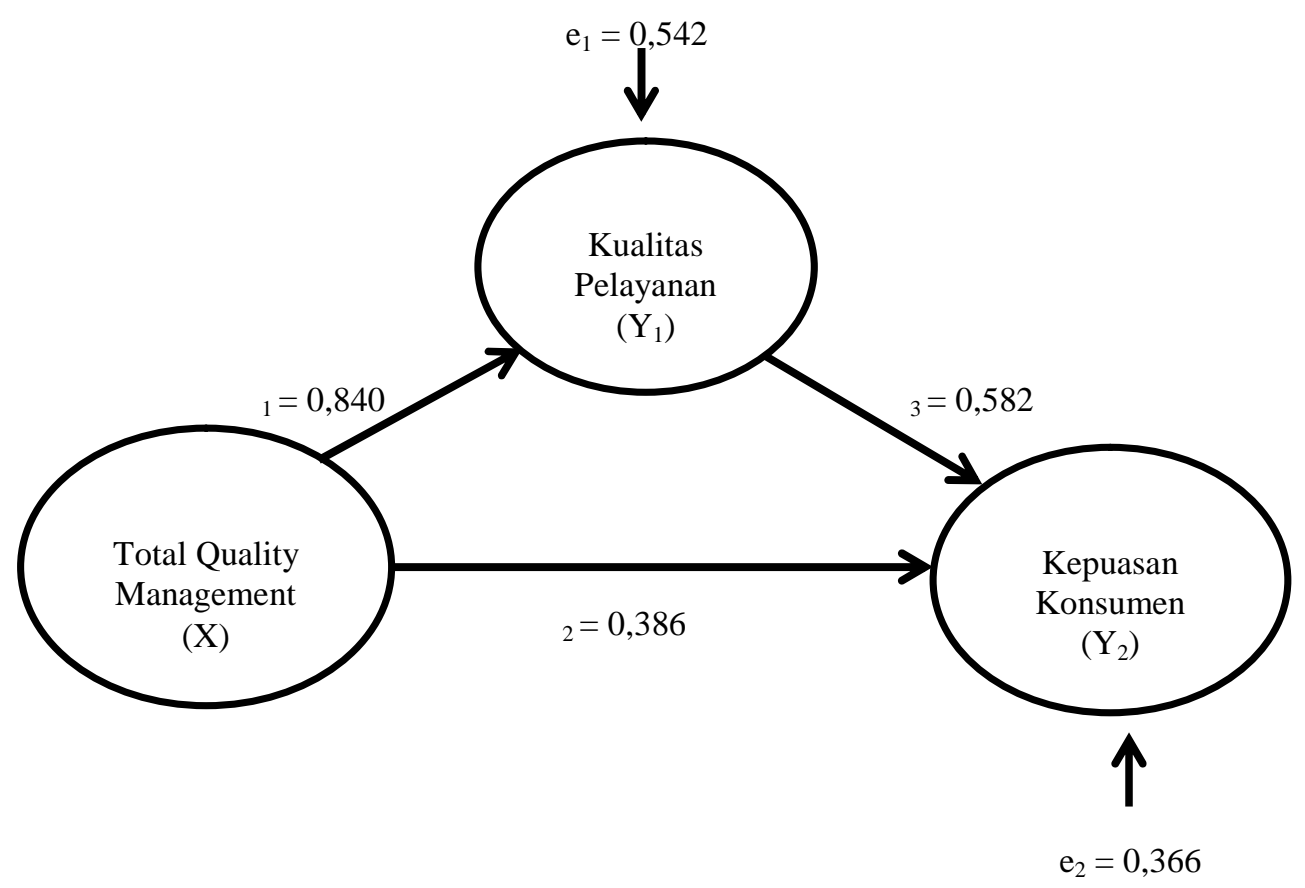

Gambar 2. Validasi Model Diagram Jalur Akhir Sumber : Data diolah, 2018

Tabel 8menunjukan nilai koefisien beta pengaruh langsung total quality management terhadap kepuasan konsumensebesar 0,386 lebih kecil dari nilai koefisien beta pengaruh tidak langsung yang dimediasi oleh kualitas pelayanan sebesar 0,489. Ini berarti kualitas pelayanan mampu memediasi total quality management terhadap kepuasan konsumen dengan pengaruh total sebesar 0,878.

Tabel 8.

Pengaruh Langsung dan Tidak Langsung serta pengaruh total Total Quality Management (X), Kualitas Pelayanan ( $\left.\mathbf{Y}_{1}\right)$ dan kepuasan Konsumen $\left(\mathbf{Y}_{2}\right)$ Pengaruh Variabel Pengaruh Pengaruh Tidak Pengaruh 


\begin{tabular}{|c|c|c|c|c|}
\hline & & Langung & $\begin{array}{c}\text { Langsung melalui } \\
\text { Kualitas } \\
\text { Pelayanan } \\
\left(\beta_{1} \times \beta_{3}\right) \\
\end{array}$ & Total \\
\hline TQM $\rightarrow$ Kualitas Pelayanan & & 0,840 & - & 0,840 \\
\hline TQM $\rightarrow$ Kepuasan Konsumen & & 0,386 & 0,489 & 0,878 \\
\hline $\begin{array}{l}\text { Kualitas Pelayanan } \rightarrow \\
\text { Konsumen }\end{array}$ & Kepuasan & 0,582 & - & 0,582 \\
\hline
\end{tabular}

Sumber : Data Diolah, 2018

Taraf nyata alpha 0,05 dan $\mathrm{Z}$ tabel 1,96 , kriteria pengujiannya adalah sebagai berikut :

$\mathrm{Z}$ hitung $\leq \mathrm{Z}$ tabel, maka $\mathrm{H}_{0}$ diterima yang berarti kualitas pelayanan $\left(\mathrm{Y}_{1}\right)$ bukan merupakan variabel mediasi.

$\mathrm{Z}$ hitung $\geq \mathrm{Z}$ tabel, maka $\mathrm{H}_{0}$ ditolak yang berarti kualitas pelayanan ( $\left.\mathrm{Y}_{1}\right)$ merupakan variabel mediasi.

Diketahui :

$$
\begin{array}{ll}
\mathrm{a} & =0,840 \\
\mathrm{~s}_{\mathrm{a}} & =0,057 \\
\mathrm{~b} & =0,582 \\
\mathrm{~s}_{\mathrm{b}} & =0,028
\end{array}
$$

Dengan menggunakan Rumus 3. Didapat hasil sebagai berikut :

$$
\begin{aligned}
& Z=\frac{0,8 \quad 0,5}{\sqrt{0,5 \quad{ }^{2} 0,0 \quad{ }^{2}+0,8}{ }^{2} 0,0 \quad{ }^{2}+0,0 \quad{ }_{0,0}^{2}}
\end{aligned}
$$

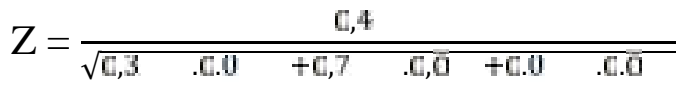

$$
\begin{aligned}
& Z=\frac{0,4}{\sqrt{0,0 \quad+0,0 \quad+2,5 \quad E-0}} \\
& \mathrm{Z}=\frac{0,4}{\sqrt{0,0}} \\
& Z=\frac{0,4}{0,0}
\end{aligned}
$$


$Z=12,0123$

Tabel 9.

Hasil Uji Sobel

\begin{tabular}{ccc}
\hline Sobel & Nilai & Keterangan \\
\hline $\mathbf{Z}$ & 12,0123 & Memediasi \\
\hline Sumber : Data diolah, 2018 & &
\end{tabular}

Hasil dari pengujian variabel mediasi pada tabel 9 dari variabel kualitas pelayanan didapatkan nilai $Z$ hitung sebesar 12,0123 yaitu lebih besar dari 1,96 ( $\mathrm{Z}$ hitung $12,0127>1,96$ ) yang berarti $\mathrm{H}_{0}$ ditolak dan $\mathrm{H}_{1}$ diterima yang berarti variabel kualitas pelayanan dinilai secara signifikan memediasi hubungan variabel total quality management terhadap kepuasan konsumen.

Penelitian ini menggunakan konsumen sebagai responden penelitian sehingga responden tidak bisa ditanyakan mengenai keseluruhan karakteristik dari total quality management yang bersifat internal perusahaan, oleh karena itu pada penelitian ini hanya digunakan tiga karakteristik dari total quality management yaitu fokus pelanggan, obsesi terhadap kualitas dan kerjasama tim sehingga variabel total quality management yang memiliki pengaruh positif dan signifikan terhadap kualitas pelayanan dan kepuasan konsumen belum sepenuhnya dapat diterima, sehingga perlu diteliti lebih lanjut menggunakan seluruh karakteristik total quality management.

\section{KESIMPULAN DAN SARAN}

Berdasarkan hasil penelitian, dan sesuai dengan tujuan penelitian maka dapat disimpulan bahwa :Terdapat pengaruh positif dan signifikan antara total quality management terhadap kualitas pelayanan.Terdapat pengaruh positif dan 
signifikan antara total quality management terhadap kepuasan konsumen. Terdapat pengaruh positif dan signifikan antara kualitas pelayanan terhadap kepuasan konsumen.Kualitas pelayanan mampu memediasi pengaruh total quality management terhadap kepuasan konsumen.

Adapun saran yang dapat diberikan yaitu : Dengan adanya pengaruh yang signifikan variabel kualitas pelayanan dalam memediasi pengaruh total quality management terhadap kepuasan konsumen maka perusahaan perlu menjaga dan meningkatkan kualitas pelayanan terutama pada kondisi sepeda dan daya tanggap dari karyawan karena dalam survey belum mendapat penilaian yang maksimal dari konsumen.Untuk meningkatkan kualitas sepeda diperlukan pemeriksaan kondisi sepeda sebelum dilakukan penggunaan jasa oleh konsumen, sehingga sepeda yang digunakan oleh konsumen layak digunakan, selain itu melakukan service secara rutin setiap bulan seperti penggantian rem, ban, dan lainlain.Kurangnya pemahaman dalam bahasa inggris yang dimiliki oleh beberapa karyawan menyebabkan karyawan tidak mengerti apa yang dibutuhkan oleh konsumen sehingga menyebabkan kurangnya penilaian terkait daya tanggap dari karyawan. Hal ini dapat diminimalisir dengan mengintensifkan proses pelatihan bahasa inggris kepada karyawan. Selain memperhatikan elemen-elemen total quality management yaitu fokus pelanggan, obsesi terhadap kualitas dan kerjasama tim, perusahaan juga perlu memperhatikan elemen-elemen total quality management yang lain seperti benchmarking atau patok duga dan continoues improvement yang dapat dijadikan sebagai dasar perbaikan kualitas secara terusmenerus untuk peningkatan kepuasan konsumen Sepeda Bali Tour.Benchmarking 
I Gede Bayu Mertha Segara,Peran Kualitas Pelayanan...

penting dilakukan untuk menemukan cara ataupun proses baru yang lebih efektif dan efisien yang dimiliki oleh perusahaan lain yang dianggap terbaik untuk meningkatkan kualitas, peningkatan keterampilan dan mengurangi biaya serta mengarah pada proses perkembangan yang berkelanjutan (Tjiptono dan Diana, 2001 : 236). Benchmarking dapat dilakukan dengan memanfaatkan penelitian sekunder untuk memperoleh data yang dimiliki oleh perusahaan patok duga, menggunakan jasa atau produk yang ditawarkan oleh perusahaan patok duga sekaligus melakukan observasi langsung, dan melakukan riset pasar serta survey mengenai kepuasan pelanggan. Sedangkan continoues improvement digunakan untuk mengantisipasi perubahan kebutuhan dan keinginan dari konsumen yang selalu berubah-ubah di masa yang akan datang. Continoues improvement hanya akan berhasil dengan disertai usaha sumber daya manusianya, dimana manajer tidak cukup hanya menerima ide perbaikan tetapi secara aktif mendorong setiap orang untuk mengidentifikasi dan menggunakan kesempatan perbaikan (Tjitono dan Diana, 2001 : 262).

\section{REFERENSI}

Alfalah, T. F. (2017). Total Quality Management Tools: Are they Necessary for Improving Service Quality and Customer Satisfaction? International Review of Management and Marketing, 7(3), 121-125. Retrieved from http://dergipark.gov.tr/download/article-file/367718

Allan, Michael Mba. (2016). The Relationship Between Service Quality and Customer Satisfaction and Retention in Ghana's Luxury Hotels. The IUP Journal of Marketing Management, 15 (4), 60-83.

Alvarez, M. Jesús., Jaca, C., Viles, E., \& Colomer, A. (2012). Quality management in hotels in the Basque Country. International Journal of Quality and Service Sciences, 4(1), 51-60. https://doi.org/10.1108/17566691211219724 
Andre, Florentina dan Tjun Lauw. (2014). Pengaruh Total Quality Management (TQM) Terhadap Kualitas Pelayanan dan Kepuasan Konsumen di Jurusan Akuntansi Fakultas Ekonomi Salah Satu Universitas di Bandung, 4 (1), 47 83.

Ashima, J. (2017). An Empirical Analysis of Customer Perception and Satisfaction of Service Quality in Public and Private Sector with specific reference to Indore Region. Advances In Management, 10 (5), 7-11.

Bakti, I Gede Mahatma Yuda., \& Sumaedi, S. (2013). An analysis of library customer loyalty:The role of service quality and customer satisfaction, a case study in Indonesia. Library Management, 34(6-7), 397-414. https://doi.org/10.1108/LM-05-2012-0025

Chen, S.-H., Chen, F.-Y., \& Wu, I.-P. (2014). An Empirical Study of TQM Method Practices for Customer Satisfaction and Customer Loyalty. International Journal of Academic Research in Business and Social Sciences, 4(5), 18-31. https://doi.org/10.6007/IJARBSS/v4-i5/820

Chiguvi, Douglas. (2016). Impact of Total Quality Management on Customer Satisfaction in the Retail Sector: Case of indigenous Supermarkets in Botswana. European Journal of Business and Management, 8 (28), 119131. https://doi.org/10.1504/IJPQM.2015.071236

Efendi, Febriani dan Mandala Kastawan. (2018). Pengaruh Implementasi Total Quality Management Terhadap Kepuasan Pelanggan Pada Perusahaan Barjaz Di Denpasar. E-Jurnal Manajemen Universitas Udayana, 7 (3), 1653-1681.

Ekoanindiyo, Firman Ardiansyah. (2010). Total Quality Management Sebagai Alat Bantu Manajemen Untuk Mencapai Optimalisasi. Dinamika Teknik, 4 (2), 44-55.

Elan, U., \& Kusmindah, D. H. (2016). Pengaruh Total Quality Management Terhadap Kepuasan Pelanggan Pada Departemen Bubi (Bidang Usaha Barang Industri) PT. Varia Usaha Di Gresik. Gema Ekonomi : Jurnal Fakultas Ekonomi, 5 (2), 178-182.

Faradina, A., \& Satrio, B. (2016). Pengaruh Promosi dan Kualitas Pelayanan Terhadap Kepuasan Pelanggan pada Rumah Cantik Almanda. Jurnal Ilmu Dan Riset Manajemen, 5(7), 1-18.

Ghozali, Imam. (2013). Aplikasi Analisis Multivariate dengan Program SPSS. Edisi Keempat, Penerbit Universitas Diponogoro. 
Hartantyo, H. T dan Hendayani, R. (2015). Analisis Implementasi Total Quality Management (Tqm) Dan Pengaruhnya Terhadap Kepuasan Konsumen Dan Service Quality. Manajemen Pemasaran, 4 (2), 136-149.

Islami, Kharisma dan Sudaryanto Budi. (2017). Pengaruh Penerapan Total Quality Management (Tqm) untuk Mengurangi Pengembalian Pekerjaan (JobReturn) sebagai Usaha dalam Memenuhi Kepuasan Pelanggan (Studi pada Pelanggan CV. AHASS Sahabat Sejati Motor di Kota Semarang). Diponegoro Journal Of Management, 6 (2), 1-8.

Kampakaki, Maria and Spyros Papathanasiou. (2016). Electronic - Banking and Customer Satisfaction in Greece. The Case of Piraeus Bank. Annals of Management Science, 5 (1), 57-71.

Kersten, W., \& Koch, J. (2010). The effect of quality management on the service quality and business success of logistics service providers. International Journal of Quality and Reliability Management, 27(2), 185-200. https://doi.org/10.1108/02656711011014302

Ooi, K. B., Lin, B., Tan, B. I., \& Chong, A. Y. L. (2011). Are TQM practices supporting customer satisfaction and service quality? Journal of Services Marketing, 25(6), 410-419. https://doi.org/10.1108/08876041111161005

Kotler, Philip. (2001). Manajemen Pemasaran : Analisis, Perencanaan, Implementasi, dan Kontrol. Jakarta : PT. Prehallindo

Philip dan Keller,Lane. (2009). Manajemen Pemasaran. Edisi Inggris Pearson Education, Edisi Indonesia PT. Indeks.

Miartana, P., Hadiwijoyo, D., \& Fatchur Rohman, S. (2014). Implementation of Total Quality Management Based Knowledge Management and Its Effect on Customer Satisfaction and Organization Performance (Studies on Four and Five Star Hotels in Bali). European Journal of Business and Management, 6(24), 98-108.

Mosahab, R., Mahamad, O., \& Ramayah, T. (2010). Service Quality, Customer Satisfaction and Loyalty: a Test of Mediation. International Business Research, 3(4), 72-80. https://doi.org/10.5539/ibr.v3n4p72

Mercy, O., \& Taiye, B. T. (2015). Strategic Imperatives of Total Quality Management and Customer Satisfaction in Organizational Sustainability. International Journal of Academic Research in Business and Social Sciences, 5(4). https://doi.org/10.6007/IJARBSS/v5-i4/1538

Pranandya, Zakiy. (2013). Pengaruh Total Quality Management Terhadap Kepuasan Pelanggan Melalui Mediasi Kualitas Pelayanan (Studi Kasus 
Pada Empat Perguruan Tinggi Swasta di Surabaya). Perpustakaan STIE Perbanas Surabaya, 1-14.

Prasojo, R. D., \& Wahyuati, A. (2016). Pengaruh Dimensi Kualitas Layanan Terhadap Kepuasan Pelanggan Ahass 0797 Kencanasari 1 Surabaya. Jurnal Ilmu Dan Riset Manajemen, 5(8), 1-18.

Priyanto. (2017). Pengaruh Kualitas Pelayanan sebagai variabel Mediasi pada Hubungan Penerapan Total Quality Education terhadap Kepuasan Mahasiswa di Politeknik Madiun. SOSIAL : Jurnal Penelitian Ilmuilmu Sosial, 18 (1), 90-113.

Ratnaningrum dan Muh. Nasron. (2013). Praktik TQM, Persepsi Kualitas Layanan Dan Kepuasan Pengujung. Benefit Jurnal Manajemen Dan Bisnis, 17 (1), 18-26.

Sakthivel, P.B., Rajendran, G. and Raju, R. (2005), “TQM Implementation: TQ Implementation And Students' Satisfaction Of Academic Performance", The TQM Magazine, 17 (6), 573-589. https://doi.org/10.1108/09544780510627660

Sugiyono. (2014). Metode Penelitian Bisnis. Bandung: Alfabeta.

Suhermini. (2010). Pengaruh Penerapan Total Qualiry Management Terhadap Kualitas Pelayanan Prima pada Aparat Kelurahan di Kecamatan Gunungpati Semarang, Jurnal Ekonomi dan Bisnis, 11(2), 231-243.

Tjiptono, Fandi. (2001). Strategi Pemasaran. Edisi Pertama. Yogyakarta : Andi Ofset.

Fandi dan Anastasia Diana. (2001). Total Quality Management (TQM). Edisi Revisi. Yogyakarta : Andi Ofset.

Review Sepeda Bali Tour. (2018). Diunduh dari Tripadvisor. website : https://www.tripadvisor.com/Attraction_Review-g297701-d3736070-

Reviews-Sepeda_Bali_Adventure_Cycling_and_ToursUbud_Gianyar_Bali.html

Utama, Made Suyana. (2016). Aplikasi Analisis Kuantitatif untuk Ekonomi dan Bisnis. Denpasar : CV Sastra Utama.

Wiharyo, S., \& Budiarti, A. (2017). Kepuasan Sebagai Mediasi Pengaruh Kualitas Layanan Dan Harga Terhadap Loyalitas Penumpang Citilink. Issn : 2461 0593, 6(3), 1-22. https://doi.org/10.1785/0120120209

Wirawan. (2012). Evaluasi : Teori, Model, Standar, Aplikasi, dan Profes. Depok : PT Raja Grafindo Persada. 
I Gede Bayu Mertha Segara,Peran Kualitas Pelayanan...

Zjulla, Nur. (2015). Implementasi Total QualityManagement Sebagai Upaya Meningkatkan Kualitas Pelayanan Di Perpustakaan Perguruan Tinggi. LIBRARIA : Jurnal Perpustakaan, 3(1), 94-109. 